\title{
Temporal dominance of sensations sensory profile and drivers of liking of artisanal Minas cheese produced in the region of Serra da Canastra, Brazil
}

\author{
Raquel M. Bemfeito, ${ }^{*}$ Jéssica F. Rodrigues, $†$ Jonas G. e Silva, ${ }^{*}$ and Luiz R. Abreu† ${ }^{1}$ \\ *Department of Agricultural Science, Federal Institute of Minas Gerais, 38900-000, Bambuí, MG, Brazil \\ †Department of Food Science, Federal University of Lavras, 37200-000, Lavras, MG, Brazil
}

\begin{abstract}
The Serra da Canastra region, located in southwestern Minas Gerais, Brazil, is recognized worldwide for its tradition of producing artisanal cheeses. However, as production is done by hand, great variability exists in the characteristics of artisanal Minas cheese. Thus, it is important to characterize the sensory profile of these products and verify the quality attributes that lead to their acceptance. Therefore, this study aimed to characterize the dynamic sensorial profile of artisanal Minas cheese produced in the Serra da Canastra region through temporal dominance of sensations and sensory acceptance tests and verify the attributes that lead to product quality. We observed that the texture and flavor profile varied among the evaluated artisanal Minas cheeses from Serra da Canastra, some cheeses being more characterized by creamy and soft or hard and firm sensations, whereas others had high dominance rates for crumbly texture. In relation to flavor, salty and bitter tastes were dominant in most cheeses, some also being characterized by a sour taste, and others by buttery and rancid attributes, which indicates a lack of product standardization. However, all samples obtained scores between 6 (liked slightly) and 7 (liked moderately), indicating good acceptability in relation to the texture and flavor of the evaluated cheeses. Moreover, it is possible to infer that creamy and soft or hard and firm are positive attributes for cheese texture, and bitter, buttery, salty, and acid taste drive cheese acceptance. This study provides important information for product standardization, quality improvement, and process origin indications, besides providing quality attributes that meet consumer desires.
\end{abstract}

Key words: acceptance, dynamic profile, artisanal cheese, temporal dominance of sensations

Received February 19, 2016.

Accepted April 28, 2016.

${ }^{1}$ Corresponding author: luizronaldo@dca.ufla.br

\section{INTRODUCTION}

Artisanal cheeses are among the major dairy products produced in many countries of Europe and the Americas (González-Córdova et al., 2016). These cheeses have great social and cultural value, as well as economic significance around the world due to their specific properties depending on the region where they are made.

In Brazil, Minas Gerais is recognized as the most traditional producing region in the country (Gomes et al., 2011), especially in the Serra da Canastra region, due to its climate, native pastures, and the artisanal process that confers a unique flavor to the product (Borelli et al., 2006). However, as reported by González-Córdova et al. (2016) for Mexican artisanal cheeses and by Marino et al. (2003) and Randazzo et al. (2009) for cheeses from many southern European countries, a lack of product standardization exists and different characteristics can be observed in cheeses from different producers. This occurs because the cheese is made with unpasteurized milk, using the endogenous microbiota found in the wheydrop (the fermented whey originating from previous production), and production is conducted on regional farms (Nóbrega, 2012; Silva et al., 2013).

Studies regarding the chemical, physical, and microbiological aspects of artisanal Minas cheese from the Serra da Canastra have been conducted (Borelli et al., 2006; Silva et al., 2011; Nóbrega, 2012; Andrade et al., 2014); however, it becomes important to characterize the sensory profile of the products and verify the quality attributes that lead to their acceptance, aiding cheese standardization, protection, and preservation of traditional artisanal production processes. Moreover, the sensory characterization provides information on their unique characteristics that makes some of them potential candidates for achieving a protected designation of origin status (PDO). This distinction could help to expand frontiers and allow the cheeses to become better known and appreciated in other parts of the world, as they consist of a typical product with export potential. 
The sensory characteristics of a food product directly influence their overall quality and define the acceptance or rejection of this product by consumers (Souza Filho and Nantes, 2004). Cheese sensory qualities can be measured by evaluating the flavor and texture sensations and through effective methods (Esmerino et al., 2015; Felicio et al., 2016).

Temporal dominance of sensations (TDS) methodology is a fast and effective method to assess the product descriptive profile (Révérend et al., 2008; Pineau et al., 2009). In combination with acceptance tests, TDS can provide important information regarding the attributes that lead to the cheese quality, as demonstrated by Deegan et al. (2013) for Emmental cheese, Rodrigues et al. (2014) for low-sodium mozzarella cheese, and Castura and Li (2016) for flavored fresh cheeses. Moreover, Rodrigues et al. (2016) emphasized that when TDS is associated with different multivariate statistical techniques, such as parallel factor analysis (PARAFAC), TDS can provide important information as to the peculiarities of each product. Therefore, our study aimed to characterize the dynamic sensory profile of artisanal Minas cheese produced in the Serra da Canastra region through TDS and sensory acceptance tests and verify the attributes that lead to product quality.

\section{MATERIALS AND METHODS}

\section{Samples}

Artisanal Minas cheese samples were used, aged 22 to $25 \mathrm{~d}$, manufactured by producers registered in the Instituto Mineiro de Agropecuária (IMA) in the towns of the Serra da Canastra microregion, comprising the municipalities Piumhi, Bambuí, Tapiraí, São Roque de Minas, Vargem Bonita, Medeiros, and Delfinópolis.

According to the census conducted by the Technical Assistance Enterprise and of Minas Gerais Rural Extension (EMATER-MG, 2004; Brazil), 44 producers are registered as Minas cheese producers. The amount of samples studied was defined according to Cochran (1977) and Ferreira (2009), which states that to be representative, for a population of less than a thousand elements the sample size should be between 10 and $20 \%$. Thus, it was established that the sample size should be $20 \%$ of the producers registered in IMA and it was divided into strata by proportional allocation on the basis of municipalities with registered producers: 1 from Bambuí, 6 from Medeiros, 2 from São Roque de Minas, and 1 from Tapiraí. The number of cheese samples chosen can be considered a convenience sampling (Felicio et al., 2013), for which the main purpose was to obtain a representative sample of the artisanal
Minas cheeses produced by registered producers (i.e., we evaluated only chesses produced according the legislation). In this particular case, the intention was to study a range of registered artisanal Minas cheeses from the Serra da Canastra region.

Cheeses were collected in 3 repetitions from 3 different batches from each producer. They were then submitted to sensorial analysis in the sensory analysis laboratory of the Food Science Department at the Federal University of Lavras. The Ethics Committee approved the study with the approval number 42588615.0.0000.5148.

\section{TDS Analysis of Minas Cheese from Serra da Canastra}

Temporal dominance of sensations tests were performed with a team of panelists, selected based on their sensory ability. Thus, 30 cheese consumers (17 women and 13 men, aged 25 to $40 \mathrm{yr}$ ), with a minimum consumption frequency of twice a week, were recruited through triangular test sessions with Prato cheese samples acquired from retail sources in Lavras, Brazil. The results of the triangular tests were analyzed using the Wald sequential analysis (Shirose, 1984).

We selected 17 panelists (11 women and 6 men, aged 25 to $40 \mathrm{yr}$ ) who participated in a familiarization session using the SensoMaker computer program (Nunes and Pinheiro, 2012) for performing TDS. The panelists were trained to recognize the specific flavors and textures that could describe the product. In the training session, references were served for each sensation involved in the analysis according to Rodrigues et al. (2016).

After training, definitive tests were performed in duplicate. In the analysis, the tasters were asked to choose the dominant sensation during the ingestion time, considering flavor perceived with greater clarity and intensity as dominant among others in a predefined list (Pineau et al., 2009). The participants were asked to place the cheese sample in their mouths and immediately begin the evaluation. The same procedure was performed to evaluate the texture.

A duration of $50 \mathrm{~s}$ was determined as the proper time to analyze each sample. Samples were evaluated for texture and flavor in different sessions by the following attributes: soft, hard, firm, creamy, crumbly, rubbery, and no perception for texture; salty, bitter, rancid, acid, buttery, sweet, spicy, and none for taste. The total analysis time was determined by pretesting and the attributes in question were determined by the Kelly network method (Kelly's repertory grid method; Moskowitz, 1983). The samples were served in a balanced way in white disposable plastic cups coded with 3-digit numbers (Macfie and Thompson, 1988). 


\section{Sensory Acceptance of Minas Cheese from Serra da Canastra}

The artisanal Minas cheese samples from the Serra da Canastra were analyzed by 60 cheese consumers (33 women and 27 men, 20 to $60 \mathrm{yr}$ of age), with a minimum consumption frequency of twice a week. They evaluated the samples in relation to texture and flavor acceptance, through acceptance tests, using a 9-point hedonic scale, ranging from 1 = extremely disliked to 9 = extremely liked according to Stone and Sidel (1993), Paixão et al. (2014), and Morais et al. (2014a).

The samples were served monadically in 2 sessions and the presentation order was determined according to the balancing proposed by Wakeling and Macfie (1995). The judges were given approximately $10 \mathrm{~g}$ of each sample at room temperature $\left(27^{\circ} \mathrm{C}\right)$ in disposable plastic cups coded with 3 -digit numbers. The test was performed with proper lighting and the absence of interference, such as noise and odors, in individual booths (Bowles and Demiate, 2006).

\section{Statistical Analysis}

TDS. Analysis of the TDS curve data was performed according to Pineau et al. (2009), using SensoMaker software (Nunes and Pinheiro, 2012). Briefly, 2 lines are drawn in the TDS graphical display: the chance level and the significance level. The chance level is the dominance rate that an attribute can obtain by chance and the significance level is the minimum value this proportion should equal to be considered significant (Pineau et al., 2009). The chance level and significance level are calculated using the confidence interval of a binomial proportion based on a normal approximation according to Pineau et al. (2009):

$$
P s=P o+1.645 \sqrt{\frac{P o(1-P o)}{n}},
$$

where $P s$ is the significantly lower ratio value ( $\mathrm{a}=$ $0.05)$ at any point in time for a TDS curve, $n$ is the number of subjects $\times$ replication, $P o$ is $1 / p$, and $p$ is the number of attributes.

After the TDS curves were constructed, PARAFAC was used to analyze the data regarding the dominance of significant sensations over time according to Rodrigues et al. (2016). One PARAFAC for texture and another for flavor were built. The PARAFAC calculations were carried out using the N-way Toolbox for Matlab (Andersson and Bro, 2000).

Sensory Acceptance. The results of the acceptance test were evaluated by an internal 2 -way prefer- ence map, using the Sensomaker software (Nunes and Pinheiro, 2012). The means and standard deviations obtained for the cheese texture and flavor acceptance were also presented.

\section{RESULTS AND DISCUSSION}

\section{Texture of Minas Cheeses from Serra da Canastra}

In the temporal texture profile of the artisanal Minas cheeses from Serra da Canastra (Figure 1), each curve represents a particular attribute of dominance over the course of time $(50 \mathrm{~s})$. The TDS curves showed that the firmness attribute was significant in every cheese evaluated [cheese (C) 1: maximum dominance rate $($ Drmax $)=0.32$, C2: Drmax $=0.42$, C3: Drmax $=$ 0.37, C4: Drmax $=0.46$, C5: Drmax $=0.36$, C6: Drmax $=0.31$, C7: Drmax $=0.49$, C8: Drmax $=0.27$, C9: Drmax $=0.47$, C10: Drmax $=0.24]$ at around $10 \mathrm{~s}$ in most samples, except sample $\mathrm{C} 8$ at which this occurred at $30.5 \mathrm{~s}$. Softness was also significantly detected at the beginning of the analysis for C1 (Drmax $=0.4)$, C3 $($ Drmax $=0.31)$, C6 $($ Drmax $=0.25)$, C9 $($ Drmax $=$ $0.24)$, and C10 (Drmax $=0.27$ ), and $46 \%$ of panelists $($ Drmax $=0.46)$ detected the hard sensation as significant for $\mathrm{C} 8$ at $10 \mathrm{~s}$.

Albert et al. (2012) noted that the initial dominant perception correlates with the fracture properties of the product as observed in this present study. This result might be justified, as the perception of textural properties is mainly related to tactile sensations, which in turn depend upon direct innervation of the inner surface of the mouth and muscle activity starting with mastication. For flavor and odor perception, a link between receptors and active molecules is needed before the perceptive process can start (Rosenthal, 1999).

Samples C8 and C10 were the only samples in which creaminess was not detected. This sensation reached maximum dominance rates ranging from $0.24(\mathrm{C} 4)$ to $0.37(\mathrm{C} 1)$ at around 25 to $35 \mathrm{~s}$. According to EMATERMG (2004), this is a characteristic attribute of artisanal chesses due to the buttery consistency of the product. Crumbliness was also detected as significantly dominant in most cheeses, except $\mathrm{C} 1$ and $\mathrm{C} 9$, and the maximum expression of this sensation occurred between 20 and 30 s. Adhikari et al. (2003) suggested that hard cheeses might maintain their integrity in the mouth longer as compared with softer products.

To summarize the texture sensorial profile of artisanal cheeses from Serra da Canastra, we optimized and adjusted a PARAFAC model (Figure 2) for the significant sensations. Thus, models using from 1 to 5 factors were generated to choose the appropriate number of elements. The core consistency value (Corcondia 

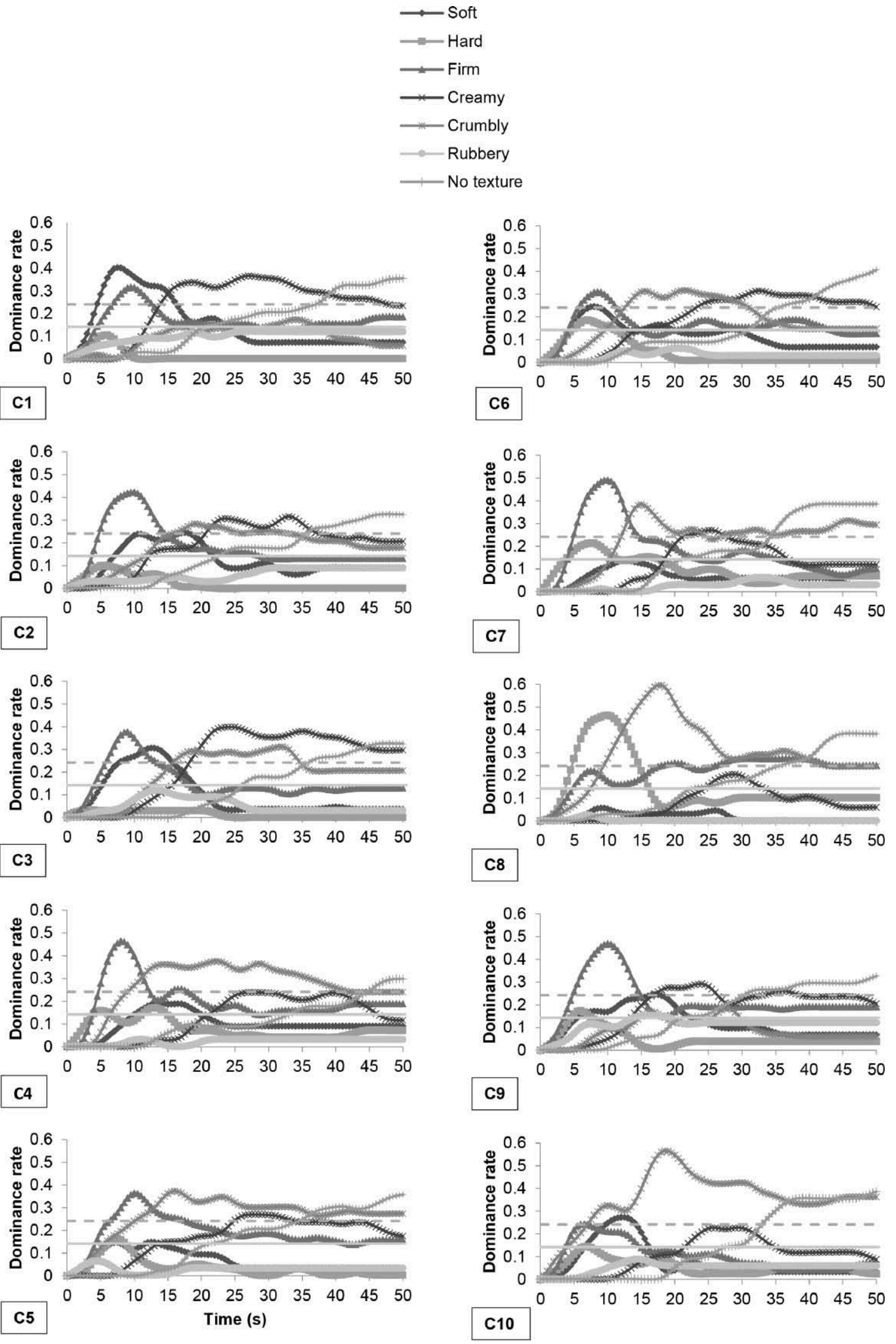

Figure 1. Temporal dominance of sensory curves related to texture for artisanal Minas cheeses (C1 to C10) from the Serra da Canastra. Journal of Dairy Science Vol. 99 No. 10, 2016 
$=94.0890 \%)$ and the percentage of variance explained (61.6770) suggested that 3 factors were present (Bro and Kiers, 2003).

The PARAFAC shows that $\mathrm{C} 1, \mathrm{C} 2, \mathrm{C} 3, \mathrm{C} 6$, and $\mathrm{C} 9$ were characterized by presenting creamy, soft, hard, and firm sensations, and $\mathrm{C} 2$ and $\mathrm{C} 9$ cheeses had greater dominance rates for these attributes up to $10 \mathrm{~s}$ of ingestion. Cheese 4, C5, C7, C8, and C10 presented as crumbly, and this sensation was expressed from around 15 to $30 \mathrm{~s}$; furthermore, from $35 \mathrm{~s}$ no texture was detected.

Texture perception of food is a dynamic process, as the physical characteristics change continuously when they are manipulated in the mouth to make food swallowable after a swallowing threshold has been reached (Jalabert-Malbos et al., 2007). Thus, TDS analysis contributes much to characterize the cheese texture perception, as it can be expressed in sensory trajectories (i.e., in terms of appearance and disappearance of dominant sensory attributes; Lenfant et al., 2009).

To assess the texture attributes that contribute to the acceptance of artisanal Minas cheese produced in the Serra da Canastra, a 2-way preference map (Figure 3) was plotted with the results obtained in the acceptance test for texture. The means of hedonic values obtained for acceptance in relation to texture of the cheeses was also shown (Table 1).

From sample organization, the group that comprised samples C1, C2, C3, and C9 was the most preferred, whereas $\mathrm{C} 4, \mathrm{C} 5, \mathrm{C} 6, \mathrm{C} 7$, and $\mathrm{C} 8$ had lower consumer acceptance. Regarding the hedonic values, all samples obtained scores between 6 (liked slightly) and 7 (liked moderately), indicating good acceptability in relation to the texture of the evaluated cheeses.

Guinard and Mazzucchelli (1996) assigned a fundamental role to textural properties affecting consumer food acceptance and preference. Based on the TDS and acceptance results it can be inferred that creamy, soft, hard, and firm, characteristic attributes of artisanal Minas cheese according to EMATER-MG (2004), are favorable to the acceptance of artisanal Minas cheeses from the Serra da Canastra. Lahne et al. (2014) also noted that these attributes are positive for Vermont artisanal cheeses. Despite crumbly seeming to be unfavorable for cheese acceptance, the samples characterized by this attribute also had good acceptance.

The texture depends on the cheese composition and structure and can be influenced by the various processing stage conditions. According to Ordóñez Pereda (2005) the cheese consistency and the taste depend heavily on the proteolysis that occurs during maturation. Through connections by calcium bridges, casein provides stability, consistency, and shape to the cheese mass (i.e., the higher the casein content, which maintains the milk fat and water content constant, the firmer the cheese
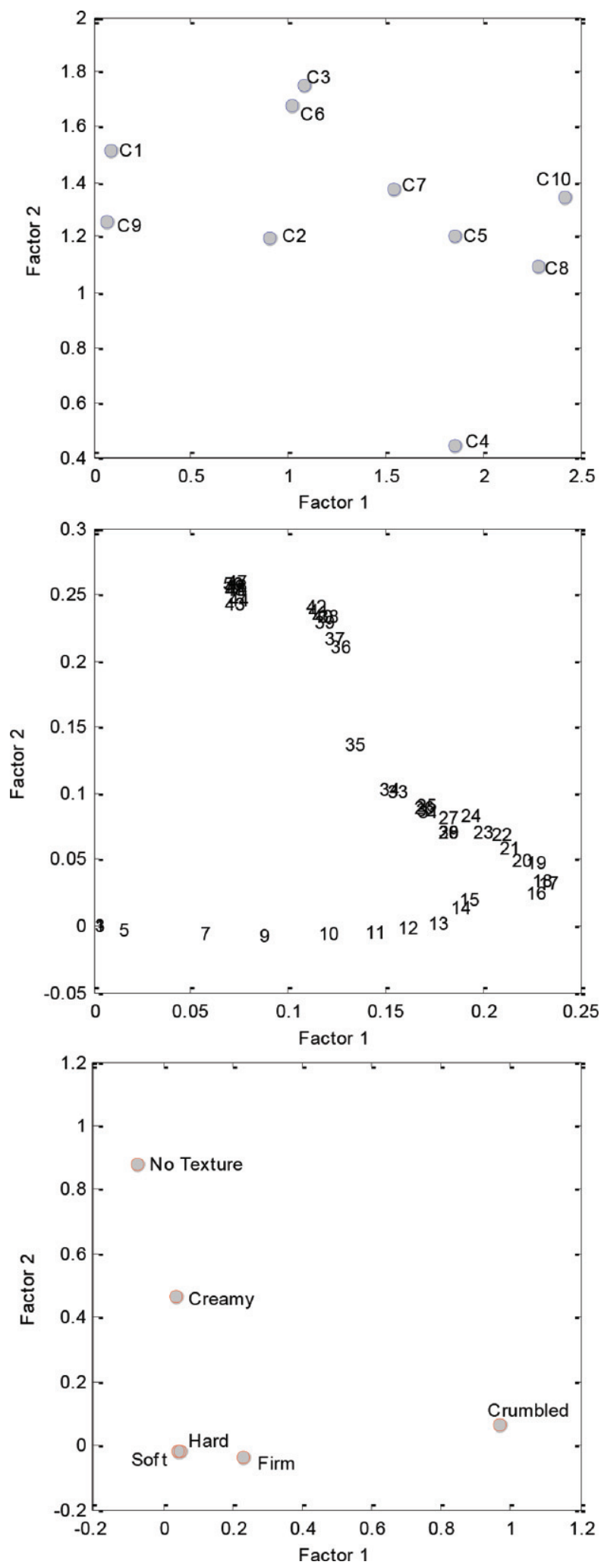

Figure 2. Parallel factor analysis of the temporal dominance of sensory profiles regarding texture attributes of artisanal Minas cheeses (C) from the Serra da Canastra: mode I (top) is the cheese samples; II (middle) is the consumption time, $50 \mathrm{~s}$; and III (bottom) is the evaluated texture sensations. Color version available online. 


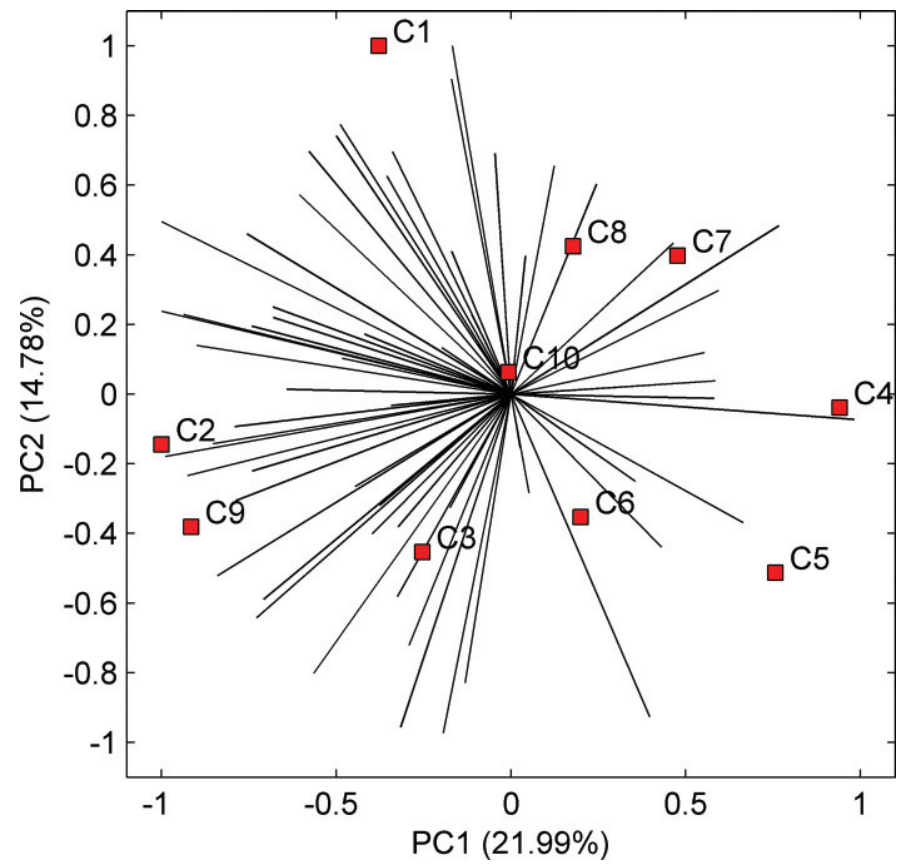

Figure 3. Preference map obtained for acceptance in relation to texture of artisanal Minas cheeses (C1 to C10) from the Serra da Canastra. Color version available online.

mass). The more calcium bound to casein, the higher the stability of the dough structure; furthermore, the production of lactic acid by the bacterial yeast, native to milk, causes the solubilization of calcium. This is due to an acidic reaction with calcium bound to the casein, forming calcium lactate, which is soluble and is lost in the whey. Thus, the higher the lactic acid production, the more calcium is withdrawn from the cheese mass and more brittle and crumbly the cheese will be.

Drake et al. (1999) and Adhikari et al. (2003) reported texture attributes for Cheddar cheeses such as firmness, cohesiveness, and adhesiveness, and for Gouda and Swiss cheese attributes such as creamy, granular, and

Table 1. Means of hedonic values obtained for acceptance in relation to texture of artisanal Minas cheeses from the Serra da Canastra ${ }^{1}$

\begin{tabular}{lc}
\hline Cheese & Texture acceptance \\
\hline C1 & $6.62 \pm 1.64$ \\
C2 & $6.73 \pm 1.55$ \\
C3 & $6.50 \pm 1.74$ \\
C4 & $6.15 \pm 1.92$ \\
C5 & $6.33 \pm 1.81$ \\
C6 & $6.67 \pm 1.80$ \\
C7 8 & $6.47 \pm 1.64$ \\
C9 & $6.67 \pm 1.96$ \\
C10 & $6.70 \pm 1.60$ \\
\hline
\end{tabular}

${ }^{1}$ Hedonic scale varying between 1 (extremely dislike) and 9 (extremely like). hardness. For Halloumi cheese, traditional in Cyprus, crumbly, elastic, moist, and gummy attributes were identified (Papademas and Robinson, 2000). According to Nóbrega (2012), artisanal cheese from the Serro region after $23 \mathrm{~d}$ of aging presented a stiffer texture, brittle and less elastic. They also noted that the cheese from the Serra da Canastra has a harder, brittle, and less elastic texture than the cheese from the Serro region. Nassu et al. (2009) evaluated the textural features of butter cheese, also known as "Cheese of the Sertão," widely consumed in northeast Brazil, and found that the crumbly texture is the most appreciated attribute that characterizes artisanal cheeses produced in the region.

\section{Flavor of Minas Cheeses from Serra da Canastra}

The flavor profile with respect to TDS of the artisanal Minas cheeses from the Serra da Canastra studied is presented in Figure 4. Each curve represents a particular attribute of dominance during the course of time (50 s). In the graphical representation of the TDS analysis, 2 lines are shown: the chance level and significance level. The chance level is the dominance rate that an attribute can obtain by chance, and the significance level is the minimum value the dominance rate should equal to be considered significant (Pineau et al., 2009).

We observed that the bitter sensation was significant in the majority of the samples $(\mathrm{C} 1, \mathrm{C} 3, \mathrm{C} 4, \mathrm{C} 5, \mathrm{C} 6, \mathrm{C} 7$ and $\mathrm{C} 9$ ), with a maximum dominance rate (Drmax) between $0.22(\mathrm{C} 9)$ and $0.42(\mathrm{C} 7)$, meaning that 22 and $42 \%$ of the panelists selected bitter as the dominant taste for $\mathrm{C} 9$ and $\mathrm{C} 7$, respectively. Regarding the time, we observed that the maximum bitter taste occurred at $9.5 \mathrm{~s}$ in $\mathrm{C} 5$, at $47 \mathrm{~s}$ in $\mathrm{C} 1$, and between 20 and $30 \mathrm{~s}$ for the other samples.

The proteolysis, protein hydrolysis during cheese aging, must be a controlled process to result in a pleasant taste and odor. In the initial stage of proteolysis casein hydrolysis occurs in larger peptides, which are degraded into smaller peptides, which can provide a bitter taste in cheeses (Hansen, 2006). The presence of these peptides is normal during the curing and the bitter taste appears only when they accumulate in the cheese.

According to Silva et al. (2011), the proteolysis rate or curing extent of artisanal cheese from the Serra da Canastra is the result of proteolytic action of enzymes of the rennet on the cheese casein. Wide variation was noted in the milk coagulation time during the cheese manufacture; thus, we concluded that there is no standardization of the amount of rennet used by farmers, which was also observed by Ordóñez Pereda (2005). The microorganisms are the fermenters primarily responsible for proteolysis of the cheese. Therefore, the 

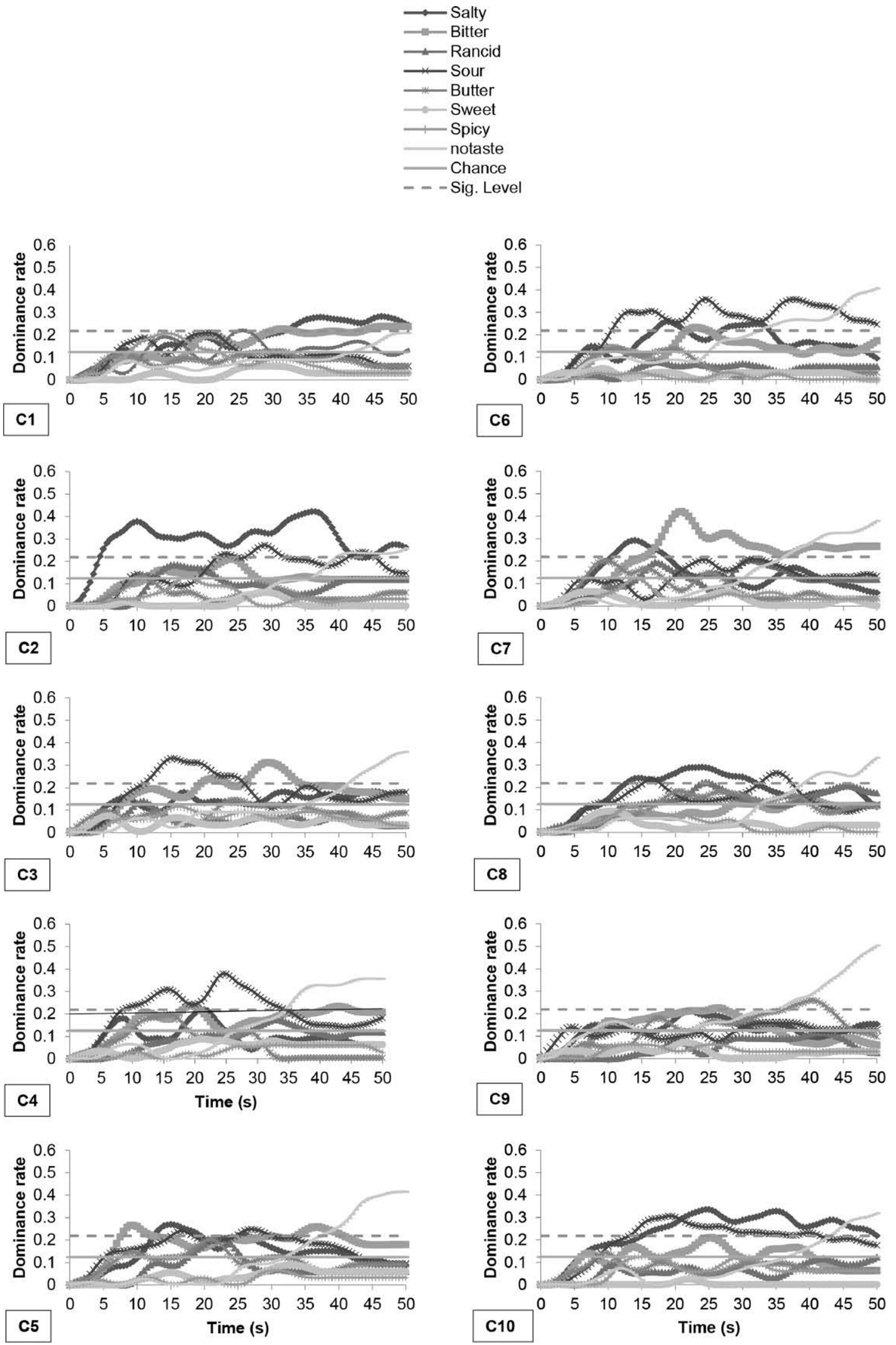

Figure 4. Temporal dominance of sensations curves related to flavor for artisanal Minas cheeses (C1 to C10) from the Serra da Canastra. 
variety of microorganisms in the wheydrop, together with the normal microbiota and contaminants in milk, contribute to variation in the proteolysis level of cheeses. Ordóñez Pereda (2005) also observed a wide variation in the amount of wheydrop used by different producers in the artisanal Minas cheese production from the Serra da Canastra. The salty taste was also significantly perceived in most samples $(\mathrm{C} 1$ : Drmax $=0.28, \mathrm{C} 2$ : Drmax $=0.42$, C5: Drmax $=0.27$, C6: Drmax $=0.26$, C7: Drmax $=0.29$, C8: Drmax $=0.29$, and C10: Drmax $=$ 0.36 ), with maximum expression between 15 and $20 \mathrm{~s}$ for $\mathrm{C} 5, \mathrm{C} 6$, and $\mathrm{C} 7$, around $25 \mathrm{~s}$ for $\mathrm{C} 8$ and $\mathrm{C} 10$, and at the end of analysis (35-40 s) for $\mathrm{C} 1$ and $\mathrm{C} 2$.

In cheesemaking, due to factors such as the cut curd grain size, lactic culture activity present in milk, amount of salt and salting method, as well as pressing duration and temperature of the pressed cheeses, variation exists in the lactic acid concentration found in each cheese. This concentration can vary even within the same batch. Thus, increased lactic acid concentration results in a $\mathrm{pH}$ decrease (Ordóñez Pereda, 2005).

In a study by Silva et al. (2011), the artisanal Minas cheese from the Serra da Canastra showed an average $\mathrm{pH}$ of 5.24, which can be explained by the cheese-pressing process, which uses hand pressure and synthetic fabric. Pressing can result in the retention of more or less lactose, with different levels of lactose being converted into lactic acid in the cheese. According to Tashakori et al. (2013), acidity is a positive attribute for the microbiological safety of cheeses.

A sour taste was significantly dominant in C2, C3, C4, C5, C6, C8, and C10, with a Drmax that ranged from $0.21(\mathrm{C} 2)$ to $0.38(\mathrm{C} 4)$, and this occurred in the middle of analysis. Moreover, $22 \%$ of the panelists detected a buttery taste as dominant in C9 at $40.5 \mathrm{~s}$. This perception is characteristic of the product, because the artisanal cheese from the Serra da Canastra is produced from raw milk with high fat content.

A rancid taste, considered a negative attribute, was significant only in samples $\mathrm{C} 1$ and $\mathrm{C} 8$ at around $25 \mathrm{~s}$, but it was not considered dominant in $\mathrm{C} 8$, because the salty taste reached a higher dominance rate than the rancid taste. This sensation is probably due to lipolytic enzyme action on milk fat (Jaeggi et al., 2003); however, low dominance rates were observed.

Significant sensations were detected from 5 to $10 \mathrm{~s}$ of ingestion in most cheeses, and in samples C1 and C9 this only occurred after 25 and 35 s. Furthermore, we observed several sensation curves between the chance and significance level, which might have occurred because of the cheese complexity (i.e., the expression of different flavors), causing the panel to have difficulty in detecting the dominant sensation.
To better visualize the similarities and differences in the sensorial profile of artisanal cheeses from the Serra da Canastra with respect to the temporal dominance of sensations profiles, a PARAFAC model of the significant sensations was optimized and adjusted. To construct the PARAFAC (Figure 5), models using 1 to 5 factors were generated to choose the appropriate number of elements. The core consistency value (Corcondia $=83.3225 \%)$ and the percentage of variance explained (68.3272) suggested that 3 factors were present (Bro and Kiers, 2003).

The PARAFAC indicated that the dominant sensations of $\mathrm{C} 1, \mathrm{C} 3, \mathrm{C} 5, \mathrm{C} 7$, and $\mathrm{C} 9$ were bitter, buttery, and rancidity, whereas the salty and acid tastes characterized samples $\mathrm{C} 2, \mathrm{C} 6$, and $\mathrm{C} 10$. Regarding the time, bitter, buttery, and rancidity sensations were more pronounced at the beginning of the analysis, in the first $15 \mathrm{~s}$, followed by the salty and sour tastes, which were expressed within 15 to $35 \mathrm{~s}$. Moreover, it is possible to infer that different sensations occurred up to $45 \mathrm{~s}$ of ingestion time.

Rodrigues et al. (2014) evaluated the sensory profile of traditional and reduced-sodium mozzarella cheese using the TDS test and observed a prevalence of the salty taste. Mamede et al. (2010) studied the sensory characteristics of curd cheese by quantitative descriptive analysis and found that, among 13 attributes evaluated, the color yellow, the typical aroma of melted cheese, and the typical flavor of curd cheese were the most important attributes to discriminate the samples. Silva et al. (2013) also used quantitative descriptive analysis to assess artisanal Minas cheese from the Serra da Canastra and found that the cheeses had an uneven coloration, crusts tending toward dry as well as oily, a strong odor, with a marked tendency toward a typical cheese odor. An acidic odor was also perceived in cheeses that had a very open texture (presence of many eyelets) and a slightly marked tendency for strong and typical flavor, in which the main problem detected by the panelists was excess salt; acid and bitter attributes were also perceived.

A 2-way preference map (Figure 6) was plotted with the results obtained in the acceptance test in relation to flavor to verify the favor sensations that direct the acceptance of artisanal Minas cheeses produced in the Serra da Canastra. The means of the hedonic values obtained for favor acceptance of the artisanal Minas cheeses from the Serra da Canastra was also presented (Table 2).

We noted that $\mathrm{C} 2, \mathrm{C} 3, \mathrm{C} 6, \mathrm{C} 8, \mathrm{C} 9$, and $\mathrm{C} 10$ had greater acceptance compared with $\mathrm{C} 1, \mathrm{C} 4, \mathrm{C} 5$, and $\mathrm{C} 7$. However, every cheese had good flavor acceptance, as most of the samples obtained hedonic values between 6 (liked slightly) and 7 (liked moderately). 

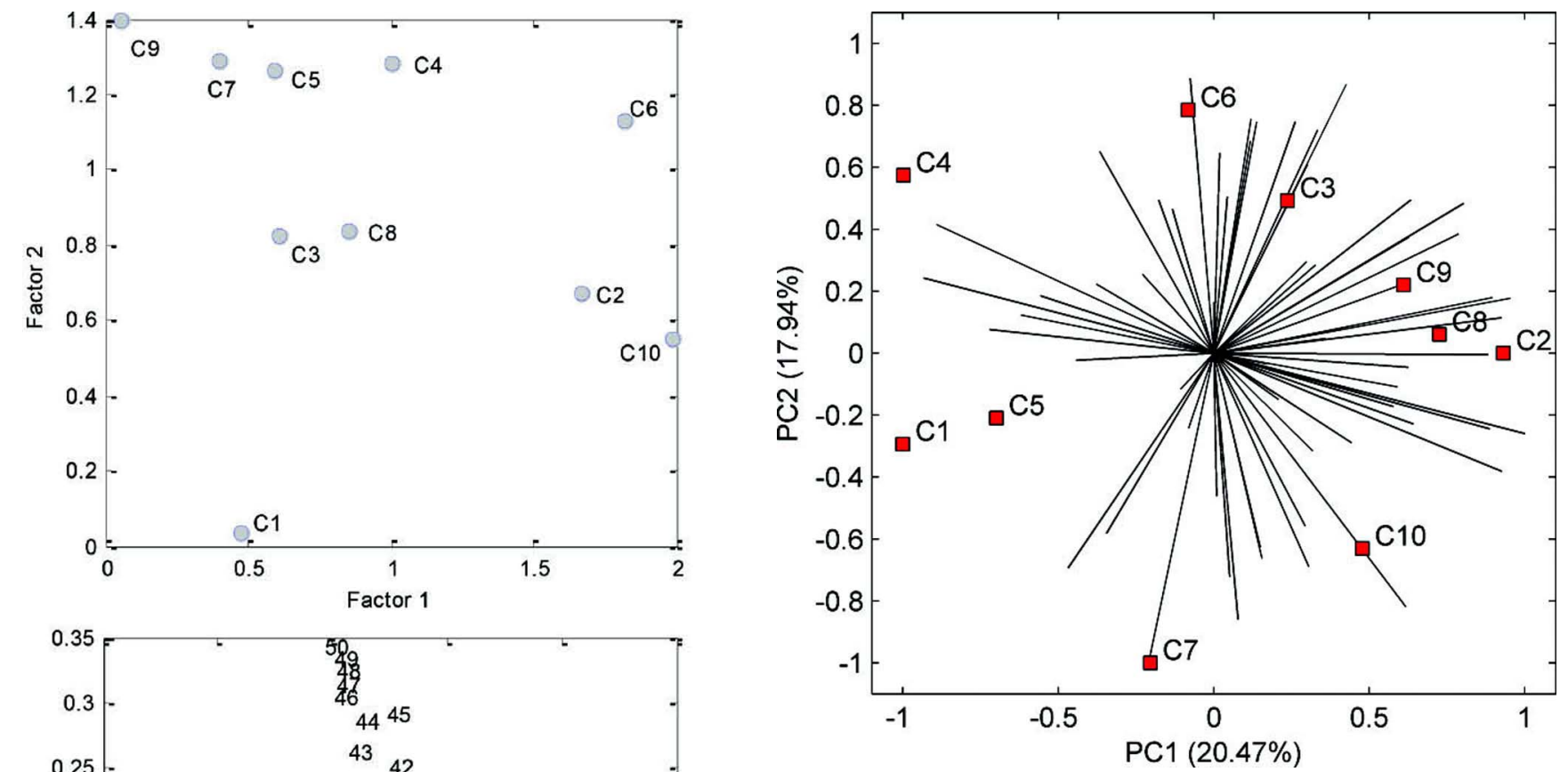

Figure 6. Preference map obtained for acceptance in relation to flavor of artisanal Minas cheeses (C1 to C10) from the Serra da Canastra. Color version available online.

In a survey conducted by Machado et al. (2004), after 600 observations of artisanal Minas cheese from Serro, an average acceptance of 6 was observed, which represents liked slightly on the hedonic scale. Resende (2014) studied the artisanal Minas cheese from the Campo das Vertentes microregion at 3 aging periods and found that cheeses cured for $10 \mathrm{~d}$ had greater acceptance, with hedonic scale indications between 7 (liked moderately) and 8 (liked a lot). Cheeses cured 20 and $30 \mathrm{~d}$ obtained a score of 6 (liked slightly), which relates to the results found in this present study that evaluated artisanal Minas cheese from the Serra da Canastra aged 22 and $25 \mathrm{~d}$.

Table 2. Means of hedonic values obtained for acceptance in relation to flavor of artisanal Minas cheeses from the Serra da Canastra ${ }^{1}$

\begin{tabular}{lc}
\hline Cheese & Flavor acceptance \\
\hline C1 & $5.97 \pm 1.76$ \\
C2 & $6.87 \pm 1.65$ \\
C3 & $6.43 \pm 1.85$ \\
C4 & $6.07 \pm 1.84$ \\
C5 & $6.20 \pm 2.11$ \\
C6 & $6.32 \pm 2.05$ \\
C8 8 & $6.06 \pm 1.86$ \\
C9 & $6.68 \pm 1.86$ \\
C10 & $6.53 \pm 1.75$ \\
\hline
\end{tabular}

Figure 5. Parallel factor analysis of the temporal dominance of sensory profiles regarding flavor attributes of artisanal Minas cheeses (C) from the Serra da Canastra: mode I (top) is the cheese samples; II (middle) is the consumption time, $50 \mathrm{~s}$; and III (bottom) is the evaluated texture sensations. Color version available online.

${ }^{1}$ Hedonic scale varying between 1 (extremely dislike) and 9 (extremely like). 
Regarding the TDS results, we noted that all attributes evaluated (bitter, buttery, salty, and acid taste) were positive for cheese acceptance, as samples from the 2 groups observed in the PARAFAC (Figure 5) are among the preferred cheeses in relation to flavor. Sant'ana et al. (2013) also observed that buttery, salty, and acid taste were positive for purchase intention of Brazilian artisanal cheese.

Although the basic process of artisanal Minas cheese making in the Serra da Canastra is common for producers, variations in the origin of the milk, the processing techniques, the aging time, and endogenous microbiota generate variety in the cheese sensory characteristics. Nóbrega (2012) evaluated 3 most characteristic samples of cheese from the Serra da Canastra and found that the cheeses differed according to their rind color uniformity, roughness, barnyard aroma, and salty and bitter taste. According to Silva et al. (2013), the artisanal Minas cheese from the Serra da Canastra presents a high variation rate in all sensory attributes analyzed. Hartmann et al. (2000) confirmed that artisanal cheeses are characterized by their high nutritional value and appreciated sensory qualities. According to the producers, raw material is primarily responsible for the flavor and maintenance of the characteristics that guarantee the product acceptance (Brant et al., 2007).

The fact that the cheeses are produced by artisanal process, with the use of unpasteurized milk from the producing farm itself, and with natural ingredients such as lactic cultures present in the wheydrop, rennet, and salt, gives the cheese peculiar sensory characteristics such as the acidity, buttery, creamy, and soft attributes detected in our study. The composition of the wheydrop is characteristic of each producing region and contains selected lactic cultures that directly influence the fermentation and maturation process, and the texture and flavor sensory profile of the Minas cheese from the Serra da Canastra region. Therefore, the wheydrop is one of the factors that most influences the product standardization.

The results of our study provide important information for dairy science, as it contributes to artisanal cheese standardization and quality improvement, besides providing the sensory attributes that meet consumer desires, increasing product competitiveness, and encouraging producers from the Serra da Canastra region and the Brazilian market. Moreover, the techniques used in the present study provide important information regarding the sensory characteristics of Brazilian cheeses, allowing them to become better known, more appreciated in other parts of the world, and showing their export potential. Furthermore, for a better characterization of artisanal Minas cheese, stud- ies covering the sensory profiling with a trained panel (Morais et al., 2014b; Gaze et al., 2015), or using novel sensory methodologies, such as Check All That Apply, projective mapping, sorting, and the intensity scale (Cruz et al., 2013; Dos Santos et al., 2015; Pereira et al., 2016), should be done.

\section{CONCLUSIONS}

We observed that the dynamic sensory profile varies widely among the evaluated artisanal Minas cheeses from the Serra da Canastra. However, all evaluated cheeses had good acceptance. Moreover, it is possible to infer that creamy, soft, hard, and firm are positive attributes for cheese texture and bitter, buttery, salty, and acid taste drive cheese acceptance. This study provides important information for product standardization and quality improvement, besides aiding in the process origin indications.

\section{ACKNOWLEDGMENTS}

We thank the Fundacao de Amparo a Pesquisa de Minas Gerais (FAPEMIG, Sao Pedro, MG, Brazil), the Conselho Nacional de Desenvolvimento Científico e Tecnológico $(\mathrm{CNPq})$, and the postgraduate program in food science of the Federal University of Lavras (Lavras, MG, Brazil) for the financial support. The use of trade names in this publication does not imply endorsement by the funding organization, the University of Lavras, or the researchers, nor does it imply criticism of materials we did not evaluate.

\section{REFERENCES}

Adhikari, K., H. Heymann, and H. E. Huff. 2003. Textural characteristics of low fat, full fat, and smoked cheeses: Sensory and instrumental approaches. Food Qual. Prefer. 14:211-218.

Albert, A., A. Salvador, P. Schlich, and S. Fiszman. 2012. Comparison between temporal dominance of sensations (TDS) and key-attribute sensory profiling for evaluating solid food with contrasting textural layers: Fish sticks. Food Qual. Prefer. 24:111-118.

Andersson, C. A., and R. Bro. 2000. The N-way toolbox for MATLAB. Chemom. Intell. Lab. Syst. 52:1-4.

Andrade, C. R. G., M. R. Souza, C. F. A. M. Penna, L. B. Acurcio, F. M. Sant'Anna, R. D. Castro, and D. L. S. Oliveira. 2014. In vitro probiotic properties of Lactobacillus spp. isolated from Minas artisanal cheese from Serra da Canastro-MG. Arq. Bras. Med. Vet. Zootec. 66:1592-1600.

Borelli, B. M., E. G. Ferreira, I. C. A. Lacerda, G. R. Fanco, and C. A. Rosa. 2006. Yeast populations associated with the artisanal cheese produced in the region of Serra da Canastra, Brazil. World J. Microbiol. Biotechnol. 22:1115-1119.

Bowles, S., and I. M. Demiate. 2006. Physicochemical characterization of the soymilk by product - okara. Cienc. Tecnol. Aliment. 26:652-659. http://dx.doi.org/10.1590/S0101-20612006000300026.

Brant, L. M. F., L. M. Fonseca, and M. C. C. Silva. 2007. Microbiological quality of artisanal Minas cheese, manufactured in the region of Serro-MG. Arq. Bras. Med. Vet. Zootec. 59:1570-1574. 
Bro, R., and H. A. L. Kiers. 2003. A new efficient method for determining the number of components in PARAFAC models. J. Chem. $17: 274-286$.

Castura, J. C., and M. Li. 2016. Using TDS dyads and other dominance sequences to characterize products and investigate liking changes. Food Qual. Prefer. 47:109-121.

Cochran, W. G. 1977. Sampling Techniques. 3rd ed. John Wiley, New York, NY

Cruz, A. G., R. S. Cadena, W. F. Castro, E. A. Esmerino, J. B Rodrigues, L. Gaze, J. A. F. Faria, M. Q. Freitas, R. Deliza, and H. M. A. Bolini. 2013. Consumer perception of probiotic yogurt: Performance of check all that apply (CATA), projective mapping, sorting and intensity scale. Food Res. Int. 54:601-610.

Deegan, K. C., N. Heikintalo, T. Ritvanen, T. Putkonen, J. Rekonen, P. L. H. Sweeney, T. Alatossava, and H. Tuorila. 2013. Effects of low-pressure homogenisation on the sensory and chemical properties of Emmental cheese. Food Sci. Emerg. Technol. 19:104-114.

Dos Santos, B. A., P. C. Bastianello Campagnol, A. G. da Cruz, M. T. E. L. Galvão, R. A. Monteiro, R. Wagner, and M. A. R. Pollonio. 2015. Check all that apply and free listing to describe the sensory characteristics of low sodium dry fermented sausages: Comparison with trained panel. Food Res. Int. 76:725-734.

Drake, M. A., P. D. Gerard, and G. V. Civille. 1999. Ability of hand evaluation versus mouth evaluation to differentiate texture of cheese. J. Sens. Stud. 14:425-441.

Empresa de Assistência Técnica e Extensão Rural de Minas Gerais (EMATER-MG). 2004. Caracterização da Microrregião da Canastra Como Produtora de Queijo Minas Artesanal. EMATER-MG, Belo Horizonte, Brazil.

Esmerino, E. A., J. A. Paixão, A. G. Cruz, L. Garitta, G. Hough, and H. M. A. Bolini. 2015. Survival analysis: A consumer-friendly method to estimate the optimum sucrose level in probiotic petit Suisse. J. Dairy Sci. 98:7544-7551.

Felicio, T. L., E. A. Esmerino, A. G. Cruz, L. C. Nogueira, R. S. L. Raices, R. Deliza, H. M. A. Bolini, and M. A. R. Pollonio. 2013. Cheese. What is its contribution to the sodium intake of Brazilians? Appetite 66:84-88.

Felicio, T. L., E. A. Esmerino, V. A. S. Vidal, L. P. Cappato, R. K. A. Garcia, R. N. Cavalcanti, M. Q. Freitas, C. A. Conte Junior, M. C. Padilha, M. C. Silva, R. S. L. Raices, D. B. Arellano, H. M. A. Bollini, M. A. R. Pollonio, and A. G. Cruz. 2016. Physico-chemical changes during storage and sensory acceptance of low sodium probiotic Minas cheese added with arginine. Food Chem. 196:628-637.

Ferreira, D. F. 2009. Basic Statistics. 2nd ed. Universidade Federal de Lavras (UFLA), Lavras, MG, Brazil.

Gaze, L. V., B. R. Oliveira, L. L. Ferrao, D. Granato, R. N. Cavalcanti, C. A. Conte Júnior, A. G. Cruz, and M. Q. Freitas. 2015. Preference mapping of dulce de leche commercialized in Brazilian markets. J. Dairy Sci. 98:1443-1454.

Gomes, A. P., A. G. Cruz, R. S. Cadena, R. M. Celeghini, J. A. Faria, H. M. Bolini, M. A. Pollonio, and D. Granato. 2011. Manufacture of low-sodium Minas fresh cheese: Effect of the partial replacement of sodium chloride with potassium chloride. J. Dairy Sci. 94:2701-2706

González-Córdova, A. F., C. Yescas, A. M. Ortiz-Estrada, M. A. De la Rosa-Alcaraz, A. Hernandez-Mendoza, and B. Vallejo-Cordoba. 2016. Invited review: Artisanal Mexican cheeses. J. Dairy Sci. 99:3250-3262.

Guinard, J. X., and R. Mazzucchelli. 1996. The sensory perception of texture and mouthfeel. Trends Food Sci. Technol. 7:213-219.

Hansen, C. 2006. Maturação de Queijos. Biotec, Valinhos, Brazil.

Hartmann, W., U. V. C. Andrade, and L. Lepka. 2000. Segurança alimentar de queijos comercializados em Curitiba-Pr. Rev. Saude Publica 6:1-13.

Jaeggi, J. J., S. Govindasamy-Lucey, Y. M. Berger, M. E. Johnson, B. C. Mckusick, D. L. Thomas, and W. L. Wendorff. 2003. Hard ewe's milk cheese manufactured from milk of three different groups of somatic cell counts. J. Dairy Sci. 86:3082-3089.

Jalabert-Malbos, M. L., A. Mishellany-Dutour, A. Woda, and M. A. Peyron. 2007. Particle size distribution in the food bolus after mastication of natural foods. Food Qual. Prefer. 18:803-812.
Lahne, J., A. B. Trubek, and M. L. Pelchat. 2014. Consumer sensory perception of cheese depends on context: A study using comment analysis and linear mixed models. Food Qual. Prefer. 32:184-197.

Lenfant, F., C. Loret, N. Pineau, C. Hartmann, and N. Martin. 2009 Perception of food oral breakdown: The concept of sensory trajectory. Appetite 52:659-667.

Macfie, H. J. H., and D. M. H. Thomson. 1988. Preference mapping and multidimensional scaling. Pages $96-101$ in Sensory Analysis of Foods. J. R. Piggott, ed. Elsevier Applied Science, New York, NY.

Machado, E. C., C. L. L. F. Ferreira, L. M. Fonseca, F. M. Soares, and F. N. Pereira Júnior. 2004. Physico-chemical and sensorial properties of artisanal Minas cheese produced in the region of Serro, Minas Gerais. Cienc. Tecnol. Aliment. (Campinas) 24:516-521.

Mamede, M. E. D. O., A. C. Viana, A. L. C. Souza, S. A. D. O. Farias, and P. A. D. Araujo. 2010. Sensorial characteristics and chemical composition of manufactured coalho cheese. Rev. Inst. Adolfo Lutz (Impr.) 69:364-370.

Marino, M., M. Maifreni, and G. Rondinini. 2003. Microbiological characterization of artisanal Montasio cheese: Analysis of its indigenous lactic acid bacteria. FEMS Microbiol. Lett. 229:133-140.

Morais, E. C., A. G. Cruz, J. A. F. Faria, and H. M. A. Bolini. 2014a Prebiotic gluten-free bread: Sensory profiling and drivers of liking. LWT Food Sci. Technol. 55:248-254.

Morais, E. C., A. R. Morais, A. G. Cruz, and H. M. A. Bolini. 2014b. Development of chocolate dairy dessert with addition of prebiotics and replacement of sucrose with different high-intensity sweeteners. J. Dairy Sci. 97:2600-2609.

Moskowitz, H. R. 1983. Product Testing and Sensory Evaluation of Foods: Marketing and R\&D Approaches. Food \& Nutrition Press, Westport, CT.

Nassu, R. T., J. R. Lima, and A. A. de Andrade. 2009. Physico chemical characterization and sensorial analysis of butter cheese made in Rio Grande do Norte - Brazil. Rev. Cienc. Agron. 40:54-59.

Nóbrega, J. E. 2012. Microbial biodiversity, physicochemical descriptors and sensory characteristics of artisan cheeses produced in the Serra da Canastra and Serro regions, Minas Gerais. 2012. Doctoral thesis. Universidade Federal de Viçosa, Viçosa, Brazil.

Nunes, C. A., and A. C. M. Pinheiro. 2012. SensoMaker. Version 1.8. Universidade Federal de Lavras, Lavras, MG, Brazil.

Ordóñez Pereda, J. A. 2005. Tecnologia de Alimentos-Origem Animal I. Artmed, São Paulo, Brazil.

Paixão, J. A., J. B. Rodrigues, E. A. Esmerino, A. G. Cruz, and H. M. A. Bolin. 2014. Influence of temperature and fat content on ideal sucrose concentration, sweetening power, and sweetness equivalence of different sweeteners in chocolate milk beverage. J. Dairy Sci. 97:7344-7353.

Papademas, P., and R. K. Robinson. 2000. A comparison of the chemical, microbiological and sensory characteristics of bovine and ovine Halloumi cheese. Int. Dairy J. 10:761-768.

Pereira, E. P. R., J. A. F. Faria, R. N. Cavalcanti, R. K. A. Garcia R. Silva, E. A. Esmerino, L. P. Cappato, D. B. Arellano, R. S L. Raices, M. C. Silva, M. C. Padilha, M. A. Meireles, H. M. A. Bolini, and A. G. Cruz. 2016. Oxidative stress in probiotic Petit Suisse: Is the jabuticaba skin extract a potential option? Food Res. Int. 81:149-156

Pineau, N., P. Schlich, S. Cordelle, C. Mathonniere, S. Issanchou, A. Imbert, M. Rogeaux, P. Etievant, and E. Koster. 2009. Temporal dominance of sensations: Construction of the TDS curves and comparison with time-intensity. Food Qual. Prefer. 20:450-455.

Randazzoa, C. L., C. Caggia, and E. Neviani. 2009. Application of molecular approaches to study lactic acid bacteria in artisanal cheeses. J. Microbiol. Methods 78:1-9.

Resende, E. C. 2014. Aspectos sensoriais e microbiológicos do queijo Minas artesanal da Microrregião Campo das Vertentes. Masters diss. Universidade Federal de Juiz de Fora, Juiz de For a, Brazil.

Révérend, F. M. L., C. Hidrio, A. Fernandes, and V. Aubry. 2008. Comparison between temporal dominance of sensations and time intensity results. Food Qual. Prefer. 19:174-178.

Rodrigues, J. F., J. P. F. Condino, A. C. M. Pinheiro, and C. A. Nunes. 2016. Temporal dominance of sensations of chocolate bars 
with different cocoa contents: Multivariate approaches to assess TDS profiles. Food Qual. Prefer. 47:91-96.

Rodrigues, J. F., C. S. Gonçalves, R. C. Pereira, J. D. S. Carneiro, and A. C. M. Pinheiro. 2014. Utilization of temporal dominance of sensations and time intensity methodology for development of lowsodium Mozzarella cheese using a mixture of salts. J. Dairy Sci. 97:4733-4744. http://dx.doi.org/10.3168/jds.2014-7913.

Rosenthal, A. J. 1999. Food Texture: Measurement and Perception. Chapman \& Hall Food Science Book. Aspen Publishers, Gaithersburg, MD.

Sant'ana, A. M., F. F. Bezerril, M. S. Madruga, A. S. Batista, M. Magnani, E. L. Souza, and R. C. Queiroga. 2013. Nutritional and sensory characteristics of Minas fresh cheese made with goat milk, cow milk, or a mixture of both. J. Dairy Sci. 96:7442-7453.

Shirose, I., and E. E. M. Mori. 1984. Aplicação da análise sequencial à seleção de provadores pelo teste triangular. Coletânea do ITAL, Campinas. 14:39-55.

Silva, J. G., L. R. Abreu, E. B. Ferreira, F. A. R. Magalhães, and R. H. Piccoli. 2011. Physico-chemical properties of handcrafted Canastra Minas cheese. Rev. Inst. Laticínios Cândido Tostes 66:16-22.
Silva, J. G., L. R. Abreu, F. A. R. Magalhães, S. M. Pinto, and R. H. Piccoli. 2013. Influência do endogenous starter culture (fermento endógeno) nas características físico-químicas e sensoriais do queijo Minas artesanal da Canastra. Informe Agropecuário 34:7-13.

Souza Filho, M. S., and J. F. D. Nantes. 2004. O QFD e a análise sensorial no desenvolvimento do produto na indústria de alimentos: perspectivas para futuras pesquisas. Pages 21-26 in Simposio De Engenharia De Produção, 11, 2004, Bauru. Anais do XI Simpósio de Engenharia de Produção. UNESP, Bauru, Brazil.

Stone, H. S., and J. L. Sidel. 1993. Sensory Evaluation Practices. Academic Press, San Diego, CA.

Tashakori, A., S. A. Y. Ardakani, and D. Daneshi. 2013. Effect of whey protein concentrate and cornstarch on chemical, rheological and sensorial properties of white Feta cheese. Am. J. Food Sci. Technol. 1:25-29.

Wakeling, I. N., and J. H. Macfie. 1995. Designing consumer trials balanced for first and higher orders of carry-over effect when only a subset of $\mathrm{k}$ samples from t may be tested. Food Qual. Prefer. 6:299-308. 